\title{
PENERAPAN PEMBELAJARAN LANGSUNG DALAM MEMFASILITASI KETERAMPILAN TEKNIK BERMAIN BOLA BASKET UNTUK SISWA TUNAGRAHITA KELAS XI SMALB-C
}

\author{
Mulya Sari \\ e-mail: ucimulyasari@gmail.com \\ SLB Kembar Karya Pembangunan I \\ Jalan Bunga Rampai III/22 Malaka Jaya, Duren Sawit, Jakarta Timur
}

\begin{abstract}
Abstrak: Kondisi Penelitian ini bertujuan untuk memfasilitasi keterampilan teknik bermain bola basket pada mata pelajaran pendidikan jasmani, olahraga dan kesehatan (Penjaskes) pada siswa tunagrahita dengan menggunakan metode pembelajaran langsung. Partisipan penelitian adalah 7 orang siswa kelas XISMALB-C, dan seorang guru. Tindakan dilakukan sebanyak 2 siklus di mana setiap siklus berlangsung dalam 2 kali pertemuan. Setiap siklus mempunyai empat kegiatan utama yaitu perencanaan, tindakan, pengamatan dan refleksi. Hasil penelitian menunjukkan adanya peningkatan hasil belajar keterampilan Penjaskes materi teknik permainan bola basket pada anak tunagrahita kelas XI SMALB-C, yang dilakukan dengan menggunakan metode pembelajaran langsung. Pembelajaran anak tunagrahita perlu mempertimbangkan penggunaan prinsip keperagaan, pengulangan dan individualisasi. Penelitian ini melaporkan bahwa metode pembelajaran langsung dapat digunakan untuk memfasilitasi keterampilan teknik bermain bola basket pada siswa tunagrahita.
\end{abstract}

Kata-kata Kunci: bermain bola basket, pembelajaran langsung, tunagrahita

\section{THE IMPLEMENTATION OF DIRECT LEARNING TO FACILITATE BASKETBALL TECHNIQUE SKILLS FOR SECOND-GRADE STUDENTS OF HIGH SCHOOL FOR STUDENTS WITH INTELLECTUAL DISABILITIES}

\begin{abstract}
This research aims to facilitate basketball technique skills in physical education, sports, and health subject for students with intellectual disability using direct learning methods. The participants of this research are seven second-grade students and a teacher of high school for students with intellectual disabilities. The actions were carried out in 2 cycles, where every cycle lasts for 2 sessions. Every cycle has four main activities; planning, action, observation, and reflection. The results showed an improvement in the learning outcomes of basketball technique skills of physical education, sports, and health subject for second-grade high school students with intellectual disability using the direct learning method. Learning for students with an intellectual disability needs to regard the use of modeling, repetition, and individualization principles. This research reported that the direct learning method could be used to facilitate basketball technique skills for students with intellectual disabilities.
\end{abstract}

Keywords: basketball, direct learning, students with intellectual disabilities 


\section{PENDAHULUAN}

Anak berkebutuhan khusus adalah anak yang memiliki kekurangan pada dirinya, salah satu kekurangan tersebut adalah gangguan intelektual atau disebut tunagrahita. Secara fisik kekurangan ini tergolong kekurangan yang tidak tampak, namun kekurangan ini dapat memberikan dampak yang sangat besar dalam kehidupan anak dengan gangguan intelektual. Hal ini dapat menghambat dalam proses komunikasi, interaksi sosial, perkembangan motorik dan kegiatan pembelajaran. Penelitian Ummah \& Arifin (2018) melaporkan bahwa siswa tunagrahita pada partisipan penelitiannya mengalami kesulitan belajar, lambat dalam merespons dan lambat dalam belajar. Berbagai upaya dilakukan untuk membekali anak dengan gangguan intelektual, agar mereka bisa bersosialisasi dalam kehidupan yang lebih layak di masyarakat.

Anak dengan keterbatasan mental biasa disebut dengan tunagrahita adalah istilah yang digunakan untuk menyebut anak yang mempunyai kemampuan intelektual di bawah rata-rata. Jamaris (2015) menuliskan retardasi mental atau dikenal dengan istilah disabilitas intelegensia atau di Indonesia dikenal dengan nama tuna grahita adalah individu yang mengalami keterbatasan mental. Anak tunagrahita karena keterbatasan kecerdasannya mengakibatkan dirinya sukar untuk mengikuti program di sekolah biasa secara klasikal. Pada masa awal perkembangan, hampir tidak ada perbedaan antara anak-anak tunagrahita dengan anak yang memiliki kecerdasan rata-rata. Akan tetapi semakin lama perbedaan pola perkembangan antara anak tunagrahita dengan anak normal semakin terlihat jelas.

Tunagrahita atau keterbelakangan mental merupakan kondisi di mana perkembangan kecerdasannya mengalami hambatan, sehingga tidak mencapai tahap perkembangan yang optimal. Menurut Somantri (2007) beberapa karakteristik umum tunagrahita adalah: 1) keterbatasan inteligensi, merupakan fungsi yang kompleks yang dapat diartikan sebagai kemampuan untuk mempelajari informasi dan keterampilan menyesuaikan diri dengan masalah dan situasi kehidupan baru, belajar dari pengalaman masa lalu, berpikir abstrak, kreatif, dapat menilai secara kritis, menghindari kesalahan-kesalahan, mengatasi kesulitan-kesulitan, dan kemampuan untuk merencanakan masa depan; 2) keterbatasan sosial, kesulitan dalam mengurus diri sendiri dalam masyarakat, cenderung berteman dengan anak yang lebih muda usianya, ketergantungan dengan orang tua sangat besar, tidak mampu memikul tanggung jawab sosial dengan bijaksana, sehingga mereka harus selalu dibimbing dan diawasi; dan 3) keterbatasan fungsi mental lainnya, seperti memerlukan waktu lebih lama untuk menyelesaikan reaksi pada situasi yang baru dikenalnya, tidak dapat menghadapi sesuatu kegiatan atau tugas dalam jangka waktu yang lama, keterbatasan dalam penguasaan bahasa, dan kurang mampu untuk mempertimbangkan sesuatu, membedakan antara yang baik dan yang buruk, dan membedakan yang benar dan yang salah.

Tunagrahita dapat dikelompokkan ke dalam lima kelompok, seperti pada tabel di bawah ini (Jamaris, 2010).

Tabel 1.

Klasifikasi Retardasi Mental

\begin{tabular}{|c|c|c|c|c|c|}
\hline \multicolumn{2}{|c|}{ Kelompok } & \multicolumn{2}{|c|}{ IQ } & \multirow{2}{*}{$\begin{array}{l}\text { Latihan } \\
\text { Pendi- } \\
\text { dikan }\end{array}$} & \multirow{2}{*}{$\begin{array}{c}\text { Kemampuan } \\
\text { Pengembangan } \\
\text { diri }\end{array}$} \\
\hline 疋 & שี & 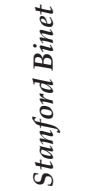 & $\frac{\grave{a}}{\frac{\pi}{0}}$ & & \\
\hline Moron & Mild & $52-68$ & $55-75$ & $\begin{array}{l}\text { Educable } \\
\text { (mampu } \\
\text { didik) }\end{array}$ & $\begin{array}{l}\text { Dapat menca- } \\
\text { pai kemampuan } \\
\text { anak usia } 7-12 \\
\text { tahun } \\
\text { Dapat menguasai } \\
\text { kemampuan aka- } \\
\text { demik setingkat } \\
\text { kelas } 4 \text { SD } \\
\text { Dapat menolong } \\
\text { diri sendiri dan } \\
\text { memiliki keter- } \\
\text { ampilan adaptasi } \\
\text { social } \\
\text { Dapat melakukan } \\
\text { pekerjaan yang } \\
\text { sederhana (un- } \\
\text { skilled work) }\end{array}$ \\
\hline $\begin{array}{l}\text { Imbe- } \\
\text { cile }\end{array}$ & $\begin{array}{l}\text { Moder- } \\
\text { ate }\end{array}$ & $36-51$ & $40-54$ & $\begin{array}{l}\text { Trainable } \\
\text { (mampu } \\
\text { latih) }\end{array}$ & $\begin{array}{l}\text { Dapat menca- } \\
\text { pai kemampuan } \\
\text { anak usia 2-7 th } \\
\text { Dapat mengua- } \\
\text { sai keterampilan } \\
\text { akademik dasar } \\
\text { secara terbatas } \\
\text { Dapat menolong } \\
\text { diri sendiri dan } \\
\text { memiliki keter- } \\
\text { ampilan sosial } \\
\text { secara terbatas } \\
\text { Dapatmelakukan } \\
\text { pekerjaan seder- } \\
\text { hana dan rutin } \\
\text { dengan supervisi } \\
\text { penuh }\end{array}$ \\
\hline
\end{tabular}




\begin{tabular}{|c|c|c|c|c|c|}
\hline \multicolumn{2}{|c|}{ Kelompok } & \multicolumn{2}{|c|}{ IQ } & \multirow{2}{*}{$\begin{array}{l}\begin{array}{c}\text { Latihan } \\
\text { Pendi- } \\
\text { dikan }\end{array} \\
\begin{array}{l}\text { Mampu } \\
\text { rawat }\end{array}\end{array}$} & \multirow{2}{*}{ 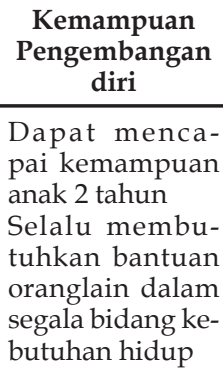 } \\
\hline Idiot & Severe & $20-35$ & $25-39$ & & \\
\hline & $\begin{array}{l}P \quad r \text { o - } \\
\text { found }\end{array}$ & $<20$ & $<25$ & $\begin{array}{l}\text { Mampu } \\
\text { rawat }\end{array}$ & $\begin{array}{l}\text { Tidak dapat } \\
\text { mencapai ke- } \\
\text { mampuan anak } \\
2 \text { tahun } \\
\text { Selalu membu- } \\
\text { tuhkan bantuan } \\
\text { orang lain dalam } \\
\text { segala bidang ke- } \\
\text { butuhan hidup }\end{array}$ \\
\hline
\end{tabular}

Mata pelajaran Pendidikan Jasmani, Olahraga dan Kesehatan (Penjaskes) memiliki peranan sangat penting, yaitu memberikan kesempatan kepada peserta didik untuk terlibat langsung dalam berbagai pengalaman belajar melalui aktivitas jasmani, olahraga dan kesehatan yang terpilih yang dilakukan secara sistematis. Pembekalan pengalaman belajar itu diarahkan untuk membina pertumbuhan fisik dan pengembangan psikis yang lebih baik, sekaligus membentuk pola hidup sehat dan bugar sepanjang hayat.

Anak tunagrahita, seperti telah dipaparkan sebelumnya, mengalami kekurangmatangan motorik dan gangguan koordinasi sensomotorik. Perkembangan motorik pada anak tunagrahita berbeda dengan anak pada umumnya. Mereka mengalami keterlambatan dalam perkembangan fisiknya. Hal ini dikarenakan mereka memiliki hambatan dalam kinerja otak yang berhubungan dengan penerimaan informasi. Proses penerimaan informasi sangat berhubungan dengan kemampuan menerima, memproses dan mengingat. Mata pelajaran Penjaskes bertujuan untuk mengembangkan kemampuan fisik yang dimiliki seseorang untuk terampil menggunakan anggota tubuhnya saat melakukan gerakan motorik kasar. Kemampuan fisik ini meliputi koordinasi, keseimbangan, keterampilan, kekuatan, kelenturan, dan kecepatan maupun kemampuan menerima rangsangan panca indera, termasuk pada siswa tunagrahita. Penelitian Holik (2016) melakukan survei pada anak tunagrahita dalam mengikuti pembelajaran Penjaskes yang hasilkan dilaporkan bahwa anak tunagrahita ringan hampir 70\% baik dalam belajar. Faktor yang mempengaruhi keaktifan belajar dapat dari internal maupun eksternal. Sementara
Pangesti \&Sudarsini (2016) mengembangkan video pembelajaran senam irama untuk digunakan dalam pembelajaran Penjaskes bagi siswa tunagrahita. Dasar pemikirannya bahwa media video merupakan media yang tepat untuk memperlihatkan contoh keterampilan yang menyangkut gerak. Dengan alat ini diperjelas baik dengan cara memperlambat ataupun mempercepat gerakan yang ditampilkan. Selain keduanya, juga ada penelitian-penelitian lain yang mengembangkan metode pembelajaran tertentu pada pembelajaran Penjaskes bagi anak tuna grahita. Hutapea (2016) melaporkan penelitian tindakan kelas yang dilakukannya pada siswa tunagrahita di SMA SLB C dengan memodifikasi permainan teknik berlari sprint. Hasilnya hampir $78 \%$ siswa dapat mencapai ketuntasan belajarnya.

Mata pelajaran Penjaskes terdapat materi bermain bola basket. Buku siswa tunagrahita kelas XI tema bangsaku terdapat beberapa teknik dasar yang harus dikuasai oleh seorang pemain basket di antaranya cara memegang bola, menangkap bola, mengoper atau melempar bola, dan menggiring bola (Umar, 2016).

Tabel 2.

Materi Teknik Bermain Basket

\begin{tabular}{|c|c|}
\hline Teknik & Hal yang harus diperhatikan \\
\hline $\begin{array}{l}\text { Memegang } \\
\text { bola basket }\end{array}$ & $\begin{array}{l}\text { a. Sikap tangan membentuk } \\
\text { mangkok besar. } \\
\text { b. Bola berada di antara kedua } \\
\text { telapak tangan. } \\
\text { c. Telapak tangan melekat di } \\
\text { samping bola agak ke belakang, } \\
\text { jari-jari terentang melekat pada } \\
\text { bola. } \\
\text { d. Ibu jari terletak dekat dengan } \\
\text { badan di bagian belakang bola } \\
\text { yang menghadap ke arah tengah } \\
\text { depan. } \\
\text { e. Kedua kaki membentuk kuda- } \\
\text { kuda dengan salah satu kaki di } \\
\text { depan. Badan sedikit condong } \\
\text { ke depan dan lutut rileks. }\end{array}$ \\
\hline $\begin{array}{l}\text { Menangkap } \\
\text { bola }\end{array}$ & $\begin{array}{l}\text { a. Menangkap bola (catching ball) } \\
\text { terdiri dari dua macam cara } \\
\text { yaitu menangkap bola di atas } \\
\text { kepala dan menangkap bola di } \\
\text { depan dada. Caranya: } \\
\text { b. Bola dijemput telapak tangan } \\
\text { dengan jari-jari tangan terentang } \\
\text { dan pergelangan tangan rileks. } \\
\text { c. Saat bola masuk di antara } \\
\text { kedua telapak tangan, jari } \\
\text { tangan segera melekat ke bola } \\
\text { dan ditarik ke belakang atau } \\
\text { mengikutiarah datangnya bola. }\end{array}$ \\
\hline
\end{tabular}




\begin{tabular}{lr}
\hline $\begin{array}{l}\text { Mengoper } \\
\text { atau }\end{array}$ & a. $\begin{array}{l}\text { Melempar bola dari atas kepala } \\
\text { (over head pass) }\end{array}$ \\
melempar & b. Melempar bola dari dari depan \\
& $\begin{array}{l}\text { dada (chest pass) yang dilakukan } \\
\text { dari dada ke dada dengan cepat } \\
\text { dalam permainan. }\end{array}$ \\
& c. Melempar bola memantul ke \\
& tanah atau lantai (bounce pass). \\
\hline
\end{tabular}

Pembelajaran langsung atau Direct Instruction (DI) dikenal dengan sebutan Active Teaching (AT), merupakan model pembelajaran yang mengarah pada prosedural. Model pembelajaran ini digunakan untuk menyampaikan pelajaran yang ditransformasikan langsung oleh guru kepada peserta didik. Dengan menggunakan model pembelajaran pembelajaran langsung, penyampaian proses keterampilan diharapkan dapat lebih mudah diberikan oleh guru. Karakteristik anak tunagrahita cenderung mengalami kesulitan dalam menerima, memproses dan mengingat berbagai stimulus yang diterima. Kesulitan tersebut dapat ditanggulangi dengan memberikan proses belajar secara langsung dan berulang-ulang. Proses belajar tersebut akan membantu mereka untuk dapat melakukan berbagai stimulus yang diberikan.

Model pembelajaran DI langsung menekankan pada penguasaan konsep dan atau perubahan perilaku dengan mengutamakan pendekatan deduktif. Pembelajaran langsung juga dinamakan whole-class teaching. Teori pendukung pembelajaran langsung adalah teori behaviorisme dan teori belajar sosial. Berdasarkan kedua teori tersebut, pembelajaran langsung menekankan belajar sebagai perubahan perilaku. Behaviorisme menekankan belajar sebagai proses stimulus-respons bersifat mekanis, teori belajar sosial beraksentuasi pada perubahan perilaku bersifat organis melalui peniruan (Suprijono, 2010). Model DI merupakan pengetahuan yang bersifat informal dan prosedural yang menjurus pada keterampilan dasar yang akan lebih efektif jika disampaikan dengan cara pembelajaran langsung. Menurut Isyani \& Esser (2017), ada pengaruh yang signifikan metode latihan bermain terhadap kemampuan melempar bola dalam permainan bola bocce pada anak tunagrahita. Maka model pembelajaran pembelajaran langsung merupakan model pembelajaran yang tepat untuk anak tunagrahita. Pembelajaran langsung dirancang untuk penguasaan pengetahuan prosedural, pengetahuan deklaratif (pengetahuan faktual) serta berbagai ketrampilan. Pembelajaran langsung dimaksudkan untuk menuntaskan dua hasil belajar yaitu penguasaan pengetahuan yang distrukturkan dengan baik dan penguasaan ketrampilan.
Model DI sudah banyak digunakan untuk mengembangkan keterampilan pada anak tunagrahita. Priambodo (2020) mengkaji literatur tentang model DI bermedia bola bocce pada kemampuan Penjas adaptif. Ia melaporkan bahwa model ini mempermudah pelaksanaan kegiatan Penjas adaptif karena dilakukan secara bertahap pada anak tunagrahita. Model ini juga digunakan untuk anak dengan hambatan motorik kasar dalam penelitian Munir (2019), melalui pemodelan senam fantasi, yang hasilnya menunjukkan bahwa ada pengaruh penggunaan model ini dengan peningkatan kemampuan motorik kasarnya. Putra \& Kasiyati (2019) memberikan intervensi melalui DI, untuk meningkatkan keterampilan menggosok gigi pada anak tunagrahita sedang. Pamuladsih (2020) juga melaporkan bahwa model pembelajaran langsung (direct instruction) melalui media benda konkret berpengaruh dalam upaya meningkatkan keterampilan vokasional siswa tunagrahita di SLB. Jadi, model ini sudah diuji efektivitas penggunaannya pada berbagai upaya peningkatan keterampilan motorik pada anak tunagrahita.

Pada kasus anak tunagrahita di kelas XI SMALB-C di wilayah Jakarta Timur, belum dapat melakukan gerakan berdasarkan perintah, dan harus dibimbing oleh guru. Apabila diberikan perintah suatu gerakan, reaksi yang diperlihatkan hanya diam saja dengan pandangan kosong kemudian kadangkala tersenyum dan menatap wajah gurunya saja. Anak akan melakukan gerakan dengan bimbingan guru itu pun guru harus membimbing setiap saat. Berdasarkan kondisi ini, penelitian pada artikel ini dilakukan dengan mengambil topik materi teknik permainan bola pada anak tunagrahita, dengan menggunakan model pembelajaran pembelajaran langsung pada anak tunagrahita kelas XI SMALB-C

\section{METODE PENELITIAN}

Penelitian ini dilaksanakan di satu Sekolah Luar Biasa (SLB) di wilayah Jakarta Timur. Partisipan dalam penelitian ini adalah peserta didik kelas XI SMALB-C pada semester II tahun pelajaran 2019/2020 dengan jumlah 7 orang anak tunagrahita. Pada penelitian ini ke-7 partisipan siswa tersebut diberikan kode Ba, An, Ad Na, Ir, Sa, Ri. Penelitian ini menggunakan metode penelitian tindakan (action research). Margaret Riel's (2007) "progressive problem solving through action research model takes the participant through four steps in each cycle: planning, taking action, collecting evidence, and reflecting" (Mertler, 2009:15), seperti pada gambar berikut ini: 


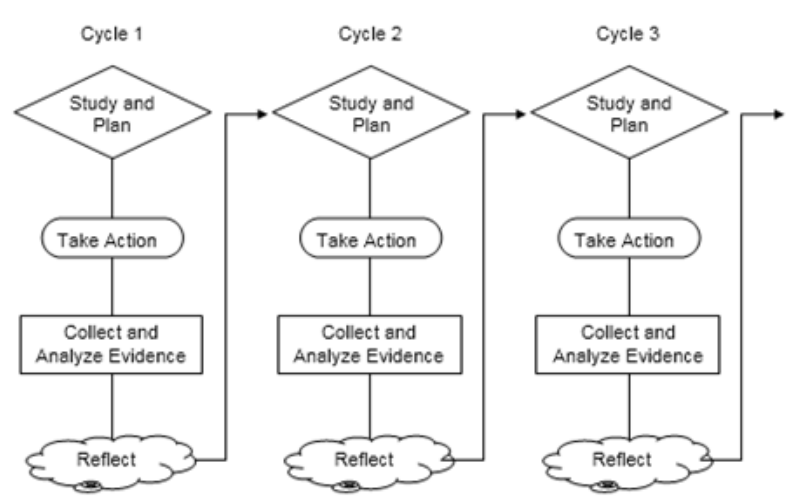

Gambar 1. Model Penelitian Tindakan yang Digunakan

Kegunaan penelitian tindakan ini adalah untuk meningkatkan hasil belajar keterampilan Penjaskes materi teknik permainan bola basket. Model pembelajaran yang digunakan adalah model pembelajaran langsung di mana pembelajaran akan dilakukan secara langsung dan berulang-ulang. Dalam penelitian ini dilaksanakan dua siklus setiap siklusnya terdapat 2 kali pertemuan. Pada siklus pertama peserta didik melakukan praktek bermain bola basket dengan bantuan guru dan pada siklus kedua peserta didik melakukannya dengan sendiri. Hasil belajar keterampilan Penjaskes materi teknik bermain bola basket perlu ditingkatkan karena memberikan banyak manfaat seperti dapat melakukan gerakan dengan pada peserta didik. Semua itu perlu dimiliki oleh peserta didik agar dapat menjadi pribadi yang mandiri. Upaya meningkatkan hasil belajar keterampilan penjaskes materi teknik bermain bola basket dilakukan pada semester II tahun ajaran 2019/2020 yang dilaksanakan setiap seminggu sekali di lapangan.

\section{HASIL DAN PEMBAHASAN}

Sebelum penelitian dilakukan peneliti dan guru Penjaskes melakukan refleksi pada ke-7 partisipan penelitian, yaitu siswa tunagrahita kelas XI SLB-C, hasilnya pada table berikut ini:

Tabel 3.

Refleksi Pra Penelitian: Profil Partisipan Penelitian

Partisipan Refleksi pada Pra Penelitian

Ba Anak yang kurang semangat dalam berolahraga, lebih senang tidur, sehingga guru harus membujuknya agar mau melakukan kegiatan olahraga. Anak yang sebenarnya mampu melakukan gerakan olahraga dengan baik, akan tetapi guru harus memujinya terlebih dahulu. Ba selalu gugup ketika mendapatkan pertanyaan, sehingga tidak bisa menjawab pertanyaan yang diberikan guru secara langsung, berbicara harus perlahan dan harus mengulang pertanyaan beberapa kali baru tugas dikerjakan, tetapi terkadang ia suka bertanya ketika yang lain sedang terdiam.

\begin{tabular}{cl}
\hline An & $\begin{array}{l}\text { Anak yang aktif dalam mengikuti kegiatan } \\
\text { pembelajaran, dan mampu melakukan gerakan } \\
\text { olahraga dengan baik. }\end{array}$ \\
\hline Ad & $\begin{array}{l}\text { Sering tidak fokus, sering termenung dan tidak } \\
\text { memperhatikan guru. Ia merupakan anak } \\
\text { yang sebenarnya mampu melakukan gerakan } \\
\text { olahraga dengan baik, akan tetapi guru harus } \\
\text { menegurnya terlebih dahulu. }\end{array}$ \\
\hline $\mathrm{Na}$ & $\begin{array}{l}\text { Anak yang aktif dan pemberani dan mampu } \\
\text { melakukan gerakan olahraga dengan baik }\end{array}$ \\
\hline $\mathrm{Ir}$ & $\begin{array}{l}\text { Sering tidak fokus, banyak berbicara, sehingga } \\
\text { membutuhkan perhatian dari guru dan guru } \\
\text { harus selalu mengingatkannya. Ia merupakan } \\
\text { anak yang sebenarnya mampu melakukan } \\
\text { gerakan olahraga dengan baik, akan tetapi guru } \\
\text { harus memperhatikannya terlebih dahulu. }\end{array}$ \\
\hline Anak yang patuh terhadap guru dan mampu \\
melakukan gerakan olahraga dengan baik.
\end{tabular}

Penelitian ini dilaksanakan dengan mengikuti sintak pembelajaran langsung (DI), yang diadaptasi dari langkah-langkah yang diajukan oleh Suprijono (2010), seperti dideskripsikan pada tabel berikut ini:

Tabel 4.

Sintak Model Pembelajaran langsung

\begin{tabular}{|c|c|}
\hline FASE-FASE & PERILAKU GURU \\
\hline $\begin{array}{l}\text { Fase 1: } \\
\text { Menyampaikan tujuan } \\
\text { dan mempersiapkan } \\
\text { peserta didik. }\end{array}$ & $\begin{array}{l}\text { Menjelaskan tujuan pembelaja- } \\
\text { ran, informasi latar belakang pe- } \\
\text { lajaran, mempersiapkan peserta } \\
\text { didik untuk belajar }\end{array}$ \\
\hline $\begin{array}{l}\text { Fase 2: } \\
\text { Mendemonstrasikan } \\
\text { pengetahuan atau ket- } \\
\text { rampilan }\end{array}$ & $\begin{array}{l}\text { Mendemonstrasikan ketrampilan } \\
\text { yang benar, menyajikan informa- } \\
\text { si tahap demi tahap }\end{array}$ \\
\hline $\begin{array}{l}\text { Fase 3: } \\
\text { Membimbing pelatih }\end{array}$ & $\begin{array}{l}\text { Merencanakan dan memberi } \\
\text { pelatihan awal }\end{array}$ \\
\hline $\begin{array}{l}\text { Fase 4: } \\
\text { Mengecek pemaha- } \\
\text { man dan memberikan } \\
\text { umpan balik }\end{array}$ & $\begin{array}{l}\text { Mengecek apakah peserta didik } \\
\text { telah berhasil melakukan tugas } \\
\text { dengan baik, memberi umpan } \\
\text { balik }\end{array}$ \\
\hline $\begin{array}{l}\text { Fase 5: } \\
\text { Memberikan kesem- } \\
\text { patan untuk pelatihan } \\
\text { lanjutan dan pener- } \\
\text { apan }\end{array}$ & $\begin{array}{l}\text { Mempersiapkan kesempatan } \\
\text { melakukan pelatihan lanjutan, } \\
\text { dengan perhatian khusus pada } \\
\text { situasi yang lebih kompleks da- } \\
\text { lam kehidupan sehari-hari. }\end{array}$ \\
\hline
\end{tabular}

Setelah dilaksanakan tindakan pada siklus I dan II, dapat direfleksikan temuan penelitian sebagai berikut:

1. Kemampuan motorik anak tunagrahita yang rendah

2. Pada kegiatan praktikum Ba, An, Ad Na, Ir, Sa, Ri, melakukan dengan ragu dan kurang hati-hati. Hal ini dikarenakan kemampuan motorik yang kurang, 
sehingga mengalami kesulitan dalam melakukan kegiatan psikomotor. Kemampuan motorik yang kurang oleh karena banyak kerusakan sel otak, anak tunagrahita mengalami gangguan motorik. Partisipan tidak dapat bergerak dengan tepat, kaku, koordinasi motorik tidak baik. Kekurangan ini dapat terlihat pada cara berjalan, lari, lompat, melempar, menulis, memotong dan pekerjaan lainnya, seperti juga diutarakan oleh Astati (2011).

3. Pembelajaran anak tunagrahita harus menggunakan prinsip keperagaan, pengulangan dan individualisasi. Anak tunagrahita mengalami hambatan dalam menerima informasi. Mereka akan cenderung diam saja jika hanya dinstruksikan dan diperagakan sekali. Mereka butuh pengulangan instruksi dan memperagakan secara jelas. Selain itu pembelajaran anak tunagrahita harus dilakukan secara individual, hal ini dikarenakan peserta didik mempunyai kemampuan yang berbeda-beda (Astati 2011).

a. Prinsip keperagaan yang digunakan dalam mengajar anak tunagrahita mengingat keterbatasan anak tunagrahita dalam berpikir abstrak.

b. Prinsip pengulangan, berhubung anak tunagrahita cepat lupa mengenai apa yang dipelajarinya, maka dalam mengajar mereka membutuhkan pengulangan-pengulangan.

c. Prinsip individualisasi, yang menekankan perhatian pada perbedaan individual anak tunagrahita, sesuai dengan iramanya sendiri.

4. Guru tunagrahita mempunyai karakteristik yang berbeda

Selama penelitian berlangsung peneliti dan kolaborator menciptakan hubungan sosioemosional yang baik terhadap peserta didik. Peserta didik yang mudah bosan dan sulit diatur harus selalu diarahkan dan dibimbing. Hal ini membuat guru mengeluarkan tenaga ekstra untuk menghadapi mereka. Guru tunagrahita harus mempunyai jiwa penyabar dalam menghadapi anak tunagrahita. Karakteristik guru yang dapat menunjang terciptanya hubungan sosio-emosional adalah disukai siswa, memiliki persepsi yang realistik tentang dirinya dan siswanya, akrab dengan siswa dalam batasan hubungan gurusiswa, bersikap positif terhadap pernyataan siswa serta sabar, teguh dan tegas (Widati, 2011).
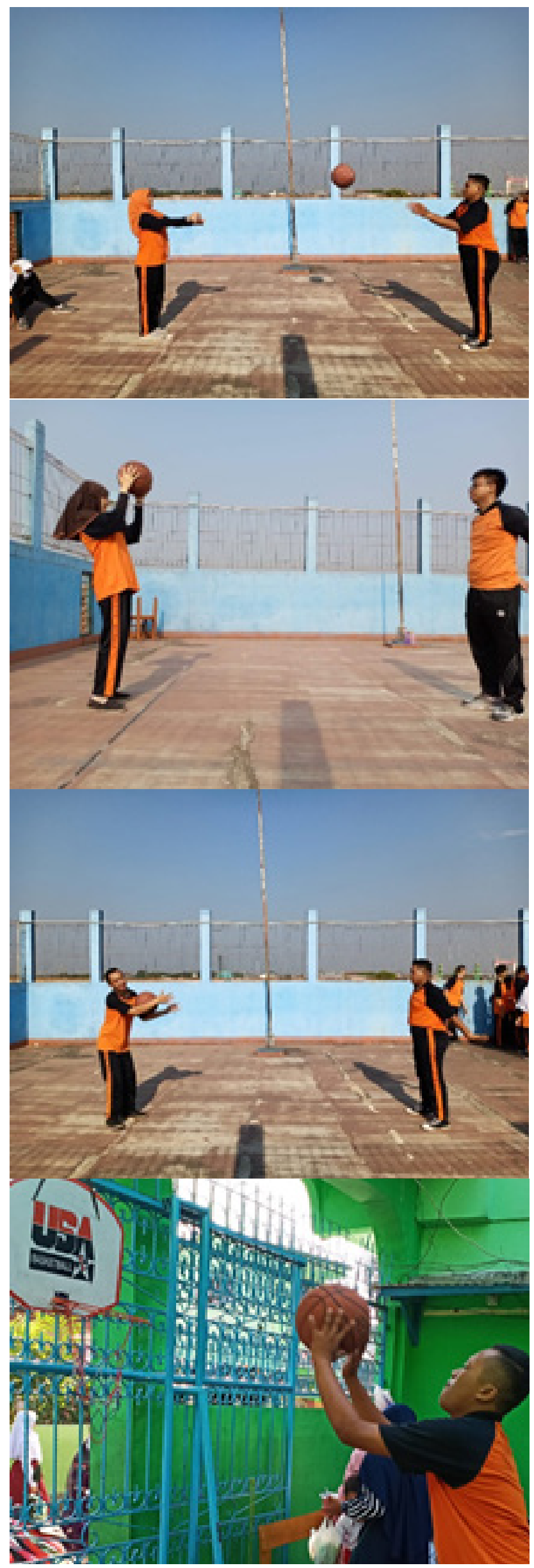

Gambar 2. Dokumentasi Praktek Keterampilan Teknik Bermain Bola Basket 
Sementara hasil belajar keterampilan teknik bermain bola basket pada siswa tunagrahita kelas XI SLB-C pada siklus I, terdapat peningkatan hasil belajarnya. Dari analisis persentasenya, terdapat peningkatan yaitu Ba sebesar $57.3 \%$, An sebesar $54.2 \%$, Ad sebesar $55.2 \%$, Na sebesar 32.3\%, Ir sebesar $42.7 \%$, Sa sebesar $60.4 \%$, Ri sebesar $31.3 \%$. Dengan demikian terdapat peningkatan hasil belajar keterampilan Penjaskes materi teknik bermain bola basket tetapi belum mencapai lebih dari 70\%. Pada siklus I, sudah terdapat peningkatan hasil belajar Penjaskes Teknik bermain bola basket. Siswa sudah dianggap mampu melakukan kegiatan materi gerak dasar. Peneliti bersama kolaborator dan orang tua dari siswa mendiskusikan untuk melanjutkan penelitian ke siklus II, agar siswa menjadi mahir melakukan kegiatan gerak dasar pada Teknik bermain bola basket. Pada tahap kemahiran siswa akan mempelajari keterampilan pada suatu tingkat automatik yang lebih baik. Tujuannya adalah agar siswa melakukan tugas dengan baik, tepat dan cepat. Penyampaian pembelajaran akan menerapkan prinsip keperagaan, pengulangan dan individualisasi. Kegiatan pemanasan akan dilakukan dengan menggunakan musik dan lagu yang dapat membuat siswa menjadi bersemangat dalam melakukan kegiatan bermain bola basket. Menurut pendapat Fani (2015), setelah diberikan intervensi berupa model pembelajaran langsung, kemampuan bercerita anak tunagrahita mengalami perubahan yang cukup baik.

Pada hasil penilaian dari siklus II, terdapat peningkatan hasil belajar keterampilan Penjaskes teknik bermain bola basket. Berdasarkan perhitungan persentase, hasil belajar keterampilan Penjaskes teknik bermain bola basket pada anak tunagrahita sudah lebih dari $70 \%$. Hal ini dapat disebabkan oleh berbagai faktor, di antaranya kegiatan pembelajaran dilakukan berulang-ulang. Dengan demikian peningkatan hasil belajar keterampilan Penjaskes materi teknik bermain bola basket sudah maksimal.

Tabel 5.

Hasil Pengamatan Hasil belajar Penjaskes Teknik Bermain Bola Basket Pra Siklus, Siklus I dan Siklus II

\begin{tabular}{ccccc}
\hline No & $\begin{array}{c}\text { Nama } \\
\text { Siswa }\end{array}$ & $\begin{array}{c}\% \\
\text { Pra } \\
\text { Tindakan }\end{array}$ & $\begin{array}{c}\% \\
\text { Siklus I }\end{array}$ & $\begin{array}{c}\% \\
\text { Siklus II }\end{array}$ \\
\hline 1 & Ba & 13.5 & 70.8 & 78.1 \\
2 & An & 11.5 & 65.6 & 76.0 \\
3 & Ad & 11.5 & 66.7 & 71.9 \\
4 & Na & 3.1 & 35.4 & 45.8 \\
5 & Ir & 5.2 & 47.9 & 74.0
\end{tabular}

\begin{tabular}{ccccc}
\hline No & $\begin{array}{c}\text { Nama } \\
\text { Siswa }\end{array}$ & $\begin{array}{c}\% \\
\text { Pra } \\
\text { Tindakan }\end{array}$ & $\begin{array}{c}\% \\
\text { Siklus I }\end{array}$ & $\begin{array}{c}\% \\
\text { Siklus II }\end{array}$ \\
\hline 6 & Sa & 13.5 & 74.0 & 84.4 \\
7 & $\mathrm{Ri}$ & 8.3 & 39.6 & 47.9 \\
\hline
\end{tabular}

Sementara, jika dilihat pada hasil belajar, memperlihatkan peningkatan hasil belajar keterampilan Penjaskes materi teknik bermain bola basket. Dengan demikian model pembelajaran pembelajaran langsung mempunyai pengaruh dalam meningkatkan hasil belajar keterampilan Penjaskes materi teknik bermain bola basket pada anak tunagrahita. Keberhasilan penelitian disimpulkan dengan mengunakan hasil persentase pada siklus terakhir di mana persentase keterampilan peserta didik melebihi $70 \%$, ini berarti hasil belajar keterampilan Penjaskes materi teknik bermain bola basket pada anak tunagrahita dapat meningkat setelah menggunakan model pembelajaran pembelajaran langsung.

\section{PENUTUP}

Anak tunagrahita memiliki keterbatasan dalam melakukan kegiatan sehari-hari. Keterampilan psikomotoriknya cenderung kurang. Hasil penelitian menunjukkan adanya peningkatan hasil belajar keterampilan Penjaskes materi teknik bermain bola basket pada peserta didik kelas XI SMALB-C yang menjadi partisipan penelitian ini. Hal ini dapat terlihat dari pengamatan dan penilaian di mana, pada siklus I ada peningkatan hasil belajar, namun belum melebihi 70\%. Kemudian pada siklus II pembelajaran menerapkan prinsip keperagaan, pengulangan dan individualisasi juga dilakukan pemanasan dengan menggunakan musik, sehingga terdapat peningkatan hasil belajar keterampilan bermain bola basket yang sudah melebihi 70\%. Peningkatan ini disebabkan oleh penggunaan penggunaan model pembelajaran direct learning yang membuat peserta didik mengetahui langkah-langkah bermain bola basket dan pembelajaran yang berulang-ulang, sehingga peserta didik mampu bola basket dengan gerak yang benar.

Penelitian ini memberikan saran pada: 1) Sekolah Luar Biasa, agar kegiatan pembelajaran dilaksanakan secara berkesinambungan, terutama pada mata pelajaran yang memberikan keterampilan pada peserta didik, dan memberikan kebebasan pada guru untuk berkreasi, sehingga tujuan pembelajaran dapat tercapai; 2) Guru, hendaknya mampu mengembangkan kemampuan dalam mengajar, 
memberikan perhatian yang sangat ekstra di dalam kelas, berkomunikasi dengan orang tua murid agar mendukung keterampilan peserta didik; 3) Orang tua hendaknya mendukung hasil pembelajaran yang telah diperoleh peserta didik; dan 4) Peneliti selanjutnya, agar meneliti efektivitas model pembelajaran direct learning dalam peningkatan keterampilan pada mata pelajaran lainnya.

\section{DAFTAR PUSTAKA}

Astati. (2011). Pendidikan Anak Tunagrahita. Bandung: Amanah Offset

Fani, Arvianti. (2015). Model Pembelajaran Langsung Terhadap Kemampuan Bercerita Anak Tunagrahita Ringan Di SLB AC. Jurnal Pendidikan Khusus. https://jurnalmahasiswa.unesa.ac.id/index. php/jurnal-pendidikan-khusus / article / viewFile/13459/12356

Holik, M. (2016). Survei Keaktifan Anak Tunagrahita dalam Mengikuti Pembelajaran Pendidikan Jasmani di SLBN 2 Pemalang Tahun 2016. Skripsi Tidak Diterbitkan. Semarang: Universitas Negeri Semarang. Diakses melalui http://lib.unnes. ac.id/26981/

Hutapea, S.A. (2016). Upaya Peningkatan Hasil Belajar Lari Sprint melalui Modifikasi Permainan pada Siswa Tunagrahita di SMA SLB C Santa Lusia Medan Tahun Ajaran 2016/2017. Skripsi Tidak Dipublikasikan. Medan: Universitas Negeri Medan. Diakses melalui http:/ / digilib.unimed. ac.id/23005/

Isyani \& Esser. (2017). Pengaruh Latihan Model Bermain Terhadap Kemampuan Melempar Bola dalam Permainan Bocce pada Anak Tunagrahita. Jurnal Kependidikan 16 (3): 256-261. http://ojs.ikipmataram.ac.id/ index.php/jurnalkependidikan/article/ download/570/536

Jamaris, Martini. (2010). Orientasi Baru Dalam Psikologi Pendidikan. Jakarta: Yayasan Panamas Murni.

Mertler, C.A. (2009). Action Research: Teachers as Researchers in the Classroom: 2nd (second) Edition. California: SAGE Publications.

Munir, M. \&Widajati. (2019). Penggunaan Metode Direct Instruction berbasis Pemodalan Senam Fantasi terhadap Motorik Kasar Anak Tunagrahita Ringan. Jurnal Pendidikan Khusus, 12 (3), 1-15. Retrieved from https:/ /jurnalmahasiswa.unesa. ac.id/index.php/jurnal-pendidikan-khusus / article/view/29829

Pamuladsih, K.D. (2020). Pengaruh Model Pembelajaran
Langsung (Direct Instruction) Melalui Media Benda Konkret untuk Meningkatkan Keterampilan Vokasional Siswa Tunagrahita di SLB Negeri Karanganyar Tahun Pelajaran 2019/2020. Skripsi Tidak Diterbitkan. Surakarta: Universitas Sebelas Maret. Diakses melalui https:// digilib.uns.ac.id/dokumen/detail/81483/ Pengaruh-Model-Pembelajaran-LangsungDirect-Instruction-Melalui-Media-BendaKonkret-untuk-Meningkatkan-KeterampilanVokasional-Siswa-Tunagrahita-di-SLB-NegeriKaranganyar-Tahun-Pelajaran-20192020

Pangesti, R. \& Sudarsini. (2015). The Development of Rhytmic Exercise Video Media in Adaptive Physical EducationLearning For Students with Intellectual Disability. Jurnal Penelitian dan Pengembangan Pendidikan Luar Biasa, 2 (1), 5-9. Retrieved from http://journal2.um.ac.id/index. php/jppplb/article/view/4323

Priambodo, A.W. (2020). Model Direct Instruction Bermedia Bola Bocce terhadap Kemampuan Penjas Adaptif Anak Tunagahita Ringan. Jurnal Pendidikan Khusus, 15 (2), . Retrieved from https://jurnalmahasiswa.unesa.ac.id/ index.php/jurnal-pendidikan-khusus / article/view/36101Soendari, Tjutju. 2011. Pembelajaran Individual dalam Pendidikan Anak Berkebutuhan Khusus. Bandung: Amanah Offset

Putra, M. \& Kasiyati. (2019). Meningkatkan Kemampuan Merawat Diri Dalam Keterampilan Menggosok Gigi Dengan Menggunakan Model Direct Instruction Pada Anak Tunagrahita Sedang. JUPPEKhu: Jurnal Penelitian Pendidikan Khusus, 7 (1), 235-242. Retrieved from http:/ / ejournal.unp.ac.id/index.php/jupekhu/article/ view/103809.

Somantri, S . (2007). Psikologi Anak Luar Biasa. Jakarta: Refika Aditama

Suprijono, A. (2009). Cooperative Learning: Teori dan Aplikasi PAIKEM. Yogyakarta: Pustaka Belajar

Ummah, D. \& Arifin, A. (2018). Analisis Kesulitan Belajar pada Anak Berkebutuhan Khusus (ABK) di SMA Negeri 10 Kota Ternate. Jurnal Bimbingan dan Konseling Terapan, 2 (1), 32-40. DOI: 10.30598/jbkt.v2i1.233.

Umar, Y. (2016). Buku Siswa Tunagrahita Kelas XI SMALB: Tema 6 Bangsaku. Jakarta : Kementerian Pendidikan dan Kebudayaan Republik Indonesia Widati, S. (2011). Pembelajaran Kreatif dalam Pendidikan Anak Berkebutuhan Khusus. Bandung: Amanah Offset 